\title{
вмJ Global Health Accelerating the SDG3 Global Action Plan
}

\author{
Maike Voss, ${ }^{1}$ Robert Marten, ${ }^{2}$ Daniel Gulati ${ }^{1}$
}

To cite: Voss M, Marten R, Gulati D. Accelerating the SDG3 Global Action Plan. BMJ Global Health 2019;4:e001930. doi:10.1136/ bmjgh-2019-001930

Handling editor Seye Abimbola

Received 21 August 2019 Accepted 27 August 2019

\section{Check for updates}

(c) Author(s) (or their employer(s)) 2019. Re-use permitted under CC BY-NC. No commercial re-use. See rights and permissions. Published by BMJ.

${ }^{1}$ Gloabl Issues Division, German Institute for International and Security Affairs, Berlin, Germany ${ }^{2}$ Global Health and Development, London School of Hygiene and Tropical Medicine, Faculty of Policy and Planning, London, UK

Correspondence to

Maike Voss;

maike.voss@swp-berlin.org
Four years after the adoption of the Agenda 2030, the implementation of the Sustainable Development Goal 3 (SDG3) 'to ensure healthy lives and well-being for all' is delayed, limited and stalling. In 2018, political leaders from Ghana, Norway and Germany requested the $\mathrm{WHO}$ and other global health-related institutions to develop a 'Global Action Plan for Healthy Lives and Well-being for All

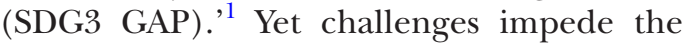
SDG3 GAP's development and implementation. The activities of numerous states and non-state actors in global health are not well coordinated and there is no accepted leadership. Global health actors are fragmented and still largely organised to meet the Millennium Development Goals (MDGs). ${ }^{2}$ It is assumed that SDG3 GAP signatories' untapped synergies simply need to be better coordinated to achieve SDG3. Instead, global health governance requires a disruptive reform. ${ }^{3}$ We believe the SDG3 GAP could lay the groundwork for such a shift.

Launched in October 2018, the SDG3 GAP has been organised around three objectives: to (1) align efforts of all signatories; (2) accelerate progress; and (3) account their collective results. ${ }^{4}$ Recently, a fourth 'A' to assess was added and an open consultation process conducted. Interested stakeholders were invited to comment on the plan and propose improvements. ${ }^{5}$ We think the SDG3 GAP can accelerate SDG3 implementation and at the same time be an instrument to explore global health governance reform. It can complement and harmonise strategies and investment cases to accelerate achieving SDG3. Yet we fear the plan, as it is currently conceptualised, perpetuates existing challenges, power relations and misses opportunities to transform global health governance.

Accordingly, we offer feedback along the latest Quadruple-A approach.

1. Assess: Harmonising signatories' different strategic approaches towards the SDGs will be a major challenge, particularly as the global political environment makes governance shifts unlikely. A preliminary comparison between the health-related SDG targets and indicators reveals gaps, for example, in terms of addressing non-communicable diseases. The GAP could add value by highlighting under represented and underfunded areas within organisations and enabling new programmes, targeting advocacy as well as reform and/or consolidation. It will be critical for the plan's success to identify gaps and suggest solutions to enable global health governance reform. Country-driven, honest dialogues between relevant actors about their shared but also conflicting interests should be the point of departure.

2. Align: The SDG3 GAP process includes a number of so-called accelerators; however, the accelerators do not necessarily reflect the views or ongoing efforts of all signatories. An initial analysis reveals contradictions between the accelerators and SDG3 targets, which seem to represent institutional priorities rather than SDG3 targets. For example, the accelerator on sustainable financing emphasises the detection, containment and prevention of infectious diseases (pandemic preparedness) to the detriment of a focus on building health systems (SDG3.8, which focuses on achieving universal health coverage). This merits further analysis and discussions. Alignment must succeed at the global and national levels with countries in the lead.

3. Accelerate: Collective and coordinated effort by the signatories is key. Those actions must balance added value of the plan at national level with the transaction cost to assess, align, accelerate and account. Critical SDG3 components are overlooked: for example, human resources for health and antimicrobial resistance. Aligning the GAP with existing strategies, road maps, frameworks and platforms is an opportunity to link the GAP to SDG3 and other thematic initiatives and therefore minimises risk of further verticalisation. The accelerators' content and 
foci should not distort national priorities. At the national level, focal points, bottom-up consultation and decision-making processes as well as governance research for all plan-related matters could support the plan's implementation. Financing the GAP could also be discussed at the United Nations High-Level Meeting on Universal Health Coverage in September.

4. Account: Governments should insist on a shared mechanism to account for the signatories' collective results, by using disaggregated data and allowing feedback from civil society. Transparency regarding the continuing development of the plan and the accelerators as well as their implementation should be fostered. This includes establishing mechanisms for civil society and community engagement. Furthermore, the proposed midpoint milestones could be used to assess health-related SDG indicators' alignment across organisations and between global and country levels. In many cases, national SDG implementation mechanisms already exist to ensure SDG incorporation into national policies and could be further leveraged.

As part of the SDG3 GAP to be launched in September, a commitment for reviewing progress with an annual road map should be part of these efforts. Moving forward, countries should use this road map to leverage their financial and structural influence, if necessary in an 'SDG3 Alliance of the Willing,' to reshape and reform the existing MDG global health architecture. After September, the GAP should take note of comparative advantages of each signatory and answer the question of what realistically will and can change at the country level and how this will be implemented to help countries accelerate progress towards SDG3.

Contributors All coauthors contributed equally.

Funding The authors have not declared a specific grant for this research from any funding agency in the public, commercial or not-for-profit sectors.

Competing interests None declared.

Patient consent for publication Not required.

Provenance and peer review Not commissioned; internally peer reviewed.

Data availability statement Data are available in a public, open access repository.

Open access This is an open access article distributed in accordance with the Creative Commons Attribution Non Commercial (CC BY-NC 4.0) license, which permits others to distribute, remix, adapt, build upon this work non-commercially, and license their derivative works on different terms, provided the original work is properly cited, appropriate credit is given, any changes made indicated, and the use is non-commercial. See: http://creativecommons.org/licenses/by-nc/4.0/.

\section{REFERENCES}

1. Merkel A, Akufo-Addo NAD, Solberg E. Letter to Dr. Tedros, general director World Health organization, 2018. Available: https://www. bundesregierung.de/resource/blob/997532/1007244/6c2d1e27d60f 916d6e9b7bafa8aea64e/2018-04-19-brief-who-englisch-data.pdf? download=1 [Accessed 13 May 2019].

2. Marten R, Kadandale S, Nordström A, et al. Shifting global health governance towards the sustainable development goals. Bull World Health Organ 2018;96:798-798A.

3. Buse K, Hawkes S. Health in the sustainable development goals: ready for a paradigm shift? Global Health 2015;11:13.

4. WHO. Towards a global action plan for healthy lives and well-being for all. Uniting to accelerate progress towards the health-related SDGs. Available: https://apps.who.int/iris/bitstream/handle/10665/311667/ WHO-DCO-2018.3-eng.pdf [Accessed 13 May 2019].

5. WHO. Invitation for public comment: global action plan for healthy lives and well-being. Available: https://www.who.int/sdg/globalaction-plan/consultations/invitation-for-public-comment-globalaction-plan-for-healthy-lives-and-well-being [Accessed 22 Jun 2019]. 